\title{
Cemaran Jamur pada Pasir Sarang Semi Alami Penyu Hijau (Chelonia mydas) di Taman Nasional Meru Betiri Banyuwangi
}

\section{Fungal Contamination on Semi Natural Hatching of Green Sea Turtle (Chelonia mydas) in Meru Betiri National Park Banyuwangi}

\author{
Abdul Latif Muhammad ${ }^{1 *}$, Jola Rahmahani², Muhammad Thohawi Elziyad Purnama ${ }^{3}$, \\ Iwan Sahrial Hamid ${ }^{4}$, Faisal Fikri ${ }^{4}$, Ratih Novita Praja ${ }^{2}$ \\ ${ }^{1}$ Pendidikan Profesi Dokter Hewan, ${ }^{2}$ Departemen Mikrobiologi Veteriner, ${ }^{3}$ Departemen Anatomi Veteriner, \\ ${ }^{4}$ Departemen Kedokteran Dasar Veteriner, \\ Fakultas Kedokteran Hewan PSDKU Banyuwangi, Universitas Airlangga, \\ J1. Wijaya Kusuma No.113, Mojopanggung, Giri, Banyuwangi \\ *Corresponding author: latif.muhammad355@gmail.com
}

\begin{abstract}
Abstrak
Tujuan dari penelitian ini adalah untuk mendeteksi adanya jamur pada sarang semi alami penyu lekang di Taman Nasional Meru Betiri Banyuwangi. Sebanyak 1 gram pasir pada 22 sarang penyu hijau digunakan sebagai sampel. Isolasi dan identifikasi dilakukan dengan pengamatan karakteristik makroskopis dari pertumbuhan koloni dan karakteristik mikroskopis dengan pewarnaan lactophenol cotton blue. Berdasarkan hasil penelitian sebanyak 3 sampel (13.6\%) negatif dan 19 sampel (83.4\%) positif terhadap pertumbuhan jamur. Beberapa jenis jamur yang telah ditemukan antara lain Aspergillus sp., Cunninghamella sp., Fusarium sp. dan Trichoderma sp.
\end{abstract}

Kata kunci: Chelonia mydas, jamur, penyu hijau, sarang semi alami

\begin{abstract}
The aim of this study was to detect the presence offungi in green turtle semi natural hatching sands in Meru Betiri National Park Banyuwangi. 1 gram of sands in 22 green turtle nests were used as the samples. Isolation and identification were performed by observation of macroscopic characteristics of colony growth and microscopic characteristics with lactophenol cotton blue staining. Based on the results of the study, 3 samples (13.6\%) were negative and 19 samples (83.4\%) were positive offungal growth. Several types of fungi that had been found were Aspergillus sp., Cunninghamella sp., Fusarium sp. and Trichoderma sp.
\end{abstract}

Key words: Chelonia mydas, fungal, green sea turtle, semi natural hatching

Received: 9 Juli 2019

Revised: 28 Juli 2019

Accepted: 18 Oktober 2019

\section{PENDAHULUAN}

Penyu Hijau (Celonia mydas) telah ditetapkan IUCN (International Union for Conservation of Nature) dalam daftar Red List kategori endangered (IUCN, 2004), sedangkan dalam CITES (Convention on International Tradein Endangered Species of Wild Flora and Fauna) dicantumkan dalam Appendix I yang artinya dilarang digunakan untuk kepentingan komersil (CITES, 2015).

Meninjau populasi penyu yang semakin berkurang setiap tahunnya, diperlukan kegiatan konservasi atau pelestarian. Konservasi merupakan salah satu kegiatan yang diharapkan dapat mencegah penyu dari kepunahan (Ario dkk., 2016).

Banyuwangi memiliki Taman Nasional Meru Betiri yang menjadi habitat penyu untuk melakukan proses bertelur dan memiliki tempat penetasan telur penyu semi alami tepatnya di Pantai Sukomade (WWF, 2009). Kegiatan konservasi dilakukan untuk mendukung progam pelestarian penyu dari berbagai ancaman seperti penangkapan penyu, perdagangan penyu serta produk turunanya (Praja dkk., 2018). Penyu Hijau 
merupakan reptil yang memiliki siklus hidup panjang. Penyu meletakkan telur-telurnya dalam timbunan pasir di pantai. Telur yang ditinggalkan di pasir akan mengalami proses inkubasi. Menurut Rafiza dkk. (2014) masa inkubasi telur pada saran g semi alami berkisar antara 53-57 hari, sehingga sangat rentan terhadap serangan mikroorganisme (Praja dkk., 2018).

Menurut Clusella dan Paladino (2007), mikroba dapat masuk melalui pori-pori dan menginfeksi telur. Mikroorganisme yang sering menyebabkan infeksi pada penyu salah satunya adalah jamur, sehingga dapat menyebabkan telur penyu gagal menetas. Jamur yang hidup di dalam pasir menginfeksi telur sehingga menyebabkan kebusukan. Telur penyu yang mengalami kebusukan akan memengaruhi telur lainnya secara langsung dan menyebabkan tingkat keberhasilan penetasan sangat kecil (Anwar dkk., 2014).

Berdasarkan penelitian yang telah dilakukan oleh Phillot and Parmenter (2001), Phillot et al. (2001), Sarmiento-Ramirez et al. (2010) ditemukan Jamur Fusarium solani pada pasir sarang penyu, tukik yang baru menetas, telur yang gagal menetas dan cangkang telur penyu Hijau, penyu Belimbing, penyu Tempayan, penyu Sisik dan penyu Pipih. Jamur Aspergillus fumigatus dan Aspergillus flavus di temukan pada cangkang telur dan pasir sarang penyu Hijau dan penyu Sisik oleh Elshafie et al. (2007), Neves et al. (2015). Laporan dari Rosado-Rodiguez and MaldonadoRamirez (2016) jamur Trichoderma longibrachiatum ditemukan pada pasir sarang penyu Belimbing. Beberapa jamur yang ditemukan pada pasir sarang penyu berpotensi zoonosis diantaranya adalah Aspergilus, Fusarium, Penicillium, Acremonium dan Trichoderma. Jamur tersebut dapat menyebabkan penyakit hyalohyphomycosis pada manusia (Grossman et al., 2012 ).

Informasi dan data terkait identifikasi jamur pada pasir sarang penetasan telur penyu semi alami di Pantai Sukomade Taman Nasional Meru Betiri belum dilaporkan. Penelitian ini bertujuan untuk mendeteksi jenis jamur pada pasir sarang yang berpotensi zoonosis, sehingga dapat mencegah terjadinya penularan penyakit dan mendukung progam konservasi penyu.

\section{METODE PENELITIAN}

Rancangan penelitian ini menggunakan metode deskriptif, yaitu melakukan penelitian dengan maksud memberikan gambaran dan penjelasan mengenai jamur apa saja yang terdapat pada pasir sarang semi alami penyu hijau dan telur penyu hijau di Taman Nasional Meru Betiri, Banyuwangi, Jawa Timur.

Sampel yang digunakan dalam penelitian adalah pasir sarang semi alami penyu Hijau di Pantai Sukomade Taman Nasional Meru Betiri Kabupaten Banyuwangi. Pengambilan sampel pada penelitian ini adalah menggunakan teknik purposive sampling. Penentuan sampel mempertimbangkan kriteria tertentu yang telah dibuat terhadap objek yang sesuai dengan tujuan penelitian (Palys, 2008).

Kriteria pemilihan sampel pada penelitian ini adalah sampel pasir diambil pada periode bongkar sarang periode November 2018 dan Februari 2019. Pasir diambil dari sarang penyu Hijau di penetasan semi alami Pantai Sukomade TNMB dengan kedalaman sarang yakni $40 \mathrm{~cm}$ menggunakan sendok spatula dan dimasukan kedalam plastik klip berlabel. Sebanyak 22 sarang dijadikan sampel dan dibawa ke Laboratorium Instrumen Universitas Airlangga PSDKU Banyuwangi untuk dilakukan pemeriksaan mikrobiologis.

Isolasi jamur dilakukan dengan mensuspensikan pasir dengan berat 1 gram ke dalam aquadest steril sebanyak $5 \mathrm{ml}$ kemudian diaduk menggunakan batang pengaduk sampai homogen. Pengambilan sampel menggunakan cotton swab celupkan kedalam suspensi pasir kemudian digoreskan (streak) pada media Saboraud Dextrose Agar (SDA). Inkubasi masing-masing sampel selama 5-7 hari dalam suhu ruang (Sanjaya, dkk. 2010).

Tahap isolasi dilanjutkan dengan identifikasi jamur yang tumbuh pada media SDA. Identifikasi jamur dilakukan berdasarkan karakteristik makroskopis dari pertumbuhan koloni serta karakteristik mikroskopis dari bentuk hifa, spora dan konidia (Al-mohanna, 2017). Tahap kedua yaitu pengamatan secara 
mikroskopis yang dilakukan dengan pewarnanaan jamur menggunakan pewarnaan lactophenol cotton blue. Pengamatan mikroskopis meliputi pengamatan terhadap bentuk hifa, dan konidia jamur menggunakan mikroskop trinokuler Nikon E-200 dengan perbesaran 40x.

\section{HASIL DAN PEMB AHASAN}

Tahap awal yang dilakukan dalam penelitian ini adalah pengambilan dan pelabelan sampel yakni pasir yang diperoleh dari sarang penyu hijau semi alami di Pantai Sukomade Taman Nasional Meru Betiri. Sejumlah 22 sampel diambil pada periode bongkar sarang di Bulan November 2018 dan Februari 2019. Pelabelan sampel diberikan angka (1-22) kemudian dilakukan isolasi dan identifikasi jamur. Sebanyak 3 sampel (13.6\%) tidak ditemui adanya pertumbuhan jamur dan 19 sampel (83.4\%) ditemukan jamur. Berdasarkan hasil penelitian berhasil ditemukan beberapa jenis jamur antara lain Aspergillus sp. (Gambar 1), Fusarium sp. (Gambar 2), Trichoderma sp. (Gambar 3) dan Cunninghamella sp. (Gambar 4) yang dapat dilihat pada Tabel 1.

Jamur Aspergillus dilaporkan Anwar dkk. (2014) menginfeksi telur penyu Lekang di penangkaran penyu Kota Pariaman, sedangkan di penangkaran Banyuwangi Sea Turtle Foundation, Praja dkk. (2018) juga menemukan jamur yang sama menginfeksi telur penyu Lekang. Guclu (2010) mengisolasi jamur Aspergillus dari sarang pasir penyu Tempayan. Mo et al. (1990) dalam penelitiannya menyatakan bahwa Aspergillus spp. ditemukan pada sarang pasir yang menetas dan dianggap sebagai salah satu jamur yang dapat mengkontaminasi melalui udara (Phillot et al., 2002). Aspergillus yang hidup di air laut dan pantai merupakan golongan kapang laut.

Kapang laut merupakan kapang yang berasal dari lingkungan darat atau air tawar yang dapat tumbuh dan bersporulasi di lingkungan laut. Jamur ini memiliki kemampuan untuk mensintesis senyawa bioaktif sebagai bentuk adaptasi terhadap kondisi lingkungan yang ekstrim (Nursid dkk., 2010). Aspergillus bersifat mikotoksigenik dalam sarang sehingga dapat menimbulkan ancaman serius bagi pertumbuhan embrio. Metabolit toksik yang dihasilkan jamur secara negatif dapat memengaruhi perkembangan embrionik tanpa kontak langsung (Elshafie et al., 2007). Jamur Aspergillus niger menghasilkan fumosins dan ochratoxin A (Frisvad et al., 2011; Purnama dan Samik, 2014), Aspergillus terreus menghasilkan citrinin, Aspergillus flavus menghasilkan aflatoxin (Elshafie et al., 2007) sedangkan Aspergillus fumigatus menghasilkan gliotoxin (Ismaiel dan Papenbrock, 2015). Menurut penelitian yang dilakukan Candan (2018) spesies Aspergillus berhasil diisolasi dari sampel pasir dan cangkang telur penyu Hijau. Aspergillus merupakan jamur yang memiliki sifat mikotoksigenik sehingga menyebabkan rendahnya angka keberhasilan penetasan telur penyu hijau yakni hanya $0.2 \%$ saja (Candan, 2018).

Jamur Fusarium merupakan salah satu jamur yang ditemukan pada pasir sarang telur penyu (Guclu et al., 2010; Sarmiento dan Ramirez, 2010). Fusarium dilaporkan bersifat sebagai parasit pada penyu terutama di bagian kepala, leher dan kulit penyu Tempayan (Peters et al., 1994). Phillot and parmenter (2001) menemukan Fusarium solani yang diisolasi dari cangkang telur gagal menetas pada sarang penyu Tempayan. Fusarium solani merupakan mycobiota umum pada tanah. Diantara jenis jamur yang diisolasi dari telur penyu Tempayan di pantai Yaniklar, Fusarium sp. paling sering ditemukan dengan presentase $53.71 \%$. Hasil penelitian ini juga menunjukkan jenis jamur Fusarium dengan presentase paling tinggi yakni $41 \%$. Genus Fusarium merupakan jenis jamur yang paling banyak ditemukan pada pasir sarang semi alami dikarenakan Fusarium sp. mikobiota umum pada tanah dan daerah dekat pantai. Jamur Fusarium ditemukan juga pada isolasi pasir sarang yang berhasil menetas, kejadian ini mengindikasikan jamur Fusarium sp. terdapat dalam pasir dan masuk ke dalam sarang sehingga mempengaruhi inkubasi dan daya tetas telur penyu (Praja dkk. 2018). Jamur ini dapat menyebabkan penyakit atau mengganggu fungsi 
Tabel 1. Hasil identifikasi jamur pada pasir sarang semi alami Pantai Sukomade

\begin{tabular}{|c|c|c|c|}
\hline No & Label Sarang & $\begin{array}{l}\text { Pertumbuhan pada } \\
\text { Media SDA }\end{array}$ & Identifikasi Jamur \\
\hline 1. & Sarang 1 & + & Fusarium sp., Cunninghamella sp. \\
\hline 2. & Sarang 2 & + & Fusarium sp \\
\hline 3. & Sarang 3 & + & Tricoderma sp. \\
\hline 4. & Sarang 4 & + & Fusarium sp., Cunninghamella sp. \\
\hline 5. & Sarang 5 & + & Fusariumsp. \\
\hline 6. & Sarang 6 & + & Fusarium sp., Aspergillus sp. \\
\hline 7. & Sarang 7 & + & Trichoderma sp. \\
\hline 8. & Sarang 8 & + & Fusariumsp. \\
\hline 9. & Sarang 9 & + & Fusarium sp., Aspergillus sp., Cunninghamella sp. \\
\hline 10. & Sarang 10 & - & 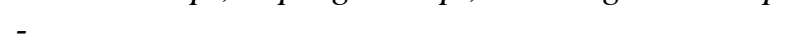 \\
\hline 11. & Sarang 11 & + & Trichoderma sp. \\
\hline 12. & Sarang 12 & + & Fusariumsp. \\
\hline 13. & Sarang 13 & + & Fusarium sp., Aspergillus sp. \\
\hline 14. & Sarang 14 & + & Trichoderma sp. \\
\hline 15. & Sarang 15 & + & Fusariumsp. \\
\hline 16. & Sarang 16 & + & Trichoderma sp. \\
\hline 17. & Sarang 17 & - & Fusarium sp., Cunninghamella sp. \\
\hline 18. & Sarang 18 & + & Aspergillus sp., Cunninghamellasp. \\
\hline 19. & Sarang 19 & + & Aspergillus sp. \\
\hline 20. & Sarang 20 & + & Fusarium sp., Aspergillus sp., Cunninghamella sp. \\
\hline 21. & Sarang 21 & - & - \\
\hline 22. & Sarang 22 & - & - \\
\hline
\end{tabular}

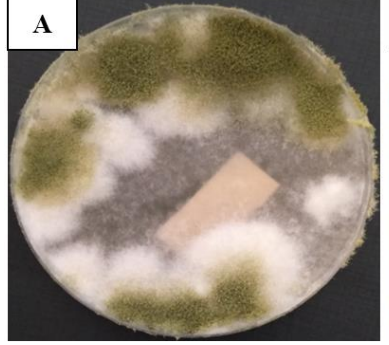

Gambar 1. Aspergillus sp.

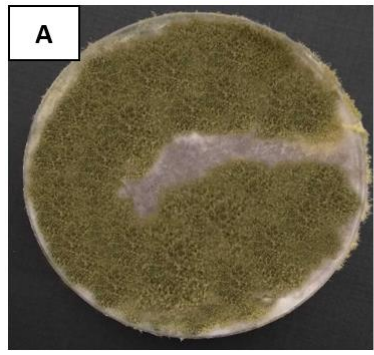

Gambar 3. Trichoderma $s p$.

sel normal karena fusarochromanone toxin yang dihasilkan (Mirocha et al., 1989).

Jamur Trichoderma pernah dilaporkan menginfeksi pada telur dan pasir sarang penyu lekang (Anwar dkk. 2014). Jamur Cunninghamella juga pernah dilaporkan oleh Phillot et al. (2001) menyerang penyu Lekang di

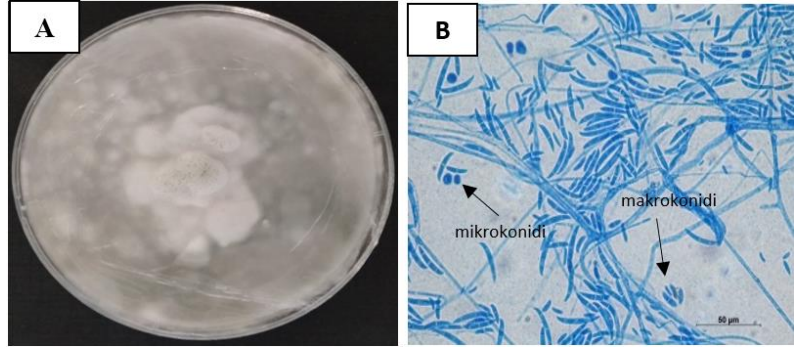

Gambar 2. Fusarium sp.
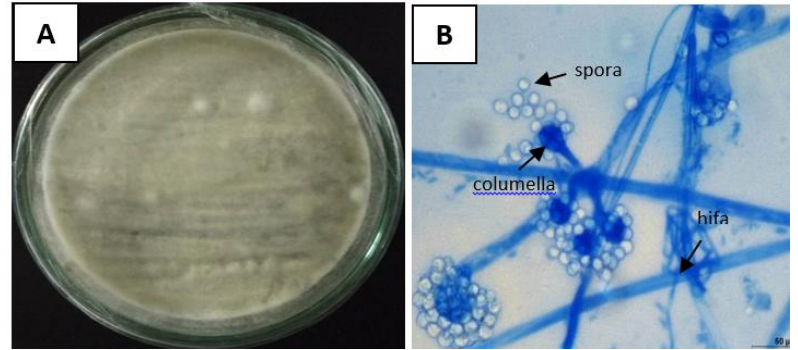

Gambar 4. Cunninghamella sp.

Nancite, Costa Rica. Infeksi jamur Trichoderma dan Cunninghamella pada penyu masih sangat jarang dilaporkan. Menurut Phillot et al. (2001), kedua jamur ini dikaitkan dengan kegagalan menetas pada telur penyu Lekang.

Berdasarkan hasil penelitian yang dilakukan, diperoleh 3 sampel (13.6\%) tidak ditemui adanya 
pertumbuhan jamur dan 19 sampel (83.4\%) ditemukan jamur. Ditemukannya jamur pada sampel pasir sarang penyu Hijau dapat dikaitkan dengan kandungan zat yang terdapat dalam telur. Telur penyu mengandung zat-zat yang sangat cocok untuk pertumbuhan embrio. Zat ini juga dimanfaatkan oleh jamur sebagai media yang sesuai bagi pertumbuhannya sehingga mampu berkembang dengan cepat dan menyebabkan telur penyu gagal menetas karena mengalami kebusukan (Bruner dan Gillespie, 1973). Keadaan ini akan bertambah buruk jika dalam satu sarang terdapat beberapa telur yang infertil atau fertil tetapi tidak mampu berkembang sempurna sehingga dapat memicu koloniasasi jamur dan mengancam perkembangan seluruh telur (Robinson et al., 2003).

Jamur yang berkembang pada pasir akan melakukan kontak dengan telur sehingga memengaruhi embrio dengan tiga cara antara lain menghambat pertukaran gas pada embrio, penipisan kalsium kulit telur sehingga memengaruhi perkembangan embrio dan melakukan transfer spora dari allantois ke jaringan embrio (Elshafie et al., 2007). Penghambatan pertukaran gas oleh jamur dilakukan dengan menutup pori-pori kulit telur sehingga menyebabkan kematian, namun hal ini tergantung dari presentase kulit telur yang tertutupi oleh jamur (Phillot and Parmenter, 2001). Penipisan kalsium pada cangkang telur dapat mengakibatkan perkembangan embrio terganggu. Kalsium yang dibutuhkan embrio dalam proses osteogenesis adalah $43 \%$ dari total kalsium pada cangkang telur (Blinski dkk., 2001). $\mathrm{CaCO}_{3}$ pada cangkang telur dimanfaatkan oleh jamur dengan cara memperkuat dinding sel serta membentuk ikatan protein-kalmodulin dan terbentuklah Ca-Kalmodulin yang berfungsi dalam aktivasi enzim-enzim sitosol (Salisbury dan Ross, 1995). Adapun faktor lain tumbuhnya jamur pada telur penyu yaitu saluran reproduksi induk penyu yang sudah terinfeksi jamur sehingga ditularkan pada telur yang dikeluarkan. Keadaan ini dapat terjadi ketika induk penyu mengalami infeksi sistemik pada oviduk, sehingga memungkinkan adanya jamur dalam telur penyu (Rafferty dan Reina, 2012). Kontaminasi jamur pada telur dapat terjadi sebelum cangkang terbentuk yang akan menginfeksi komponen telur, hal ini dapat terjadi ketika uterus dan ovarium induk terinfeksi jamur (Elfidasari dkk. 2017).

Sebanyak 3 sarang dalam penelitian tidak ditemukan adanya pertumbuhan jamur pada SDA. Data tersebut dikaitkan dengan pendapat Simbolon (2008), terdapat persaingan diantara mikroorganisme pada pasir sarang semi alami pasca menetas. Diduga jamur kalah bersaing dalam memeanfaatkan nutrisi untuk dapat tumbuh dan berkembang. Keberadaan koloni jamur pada pasir semi alami disebabkan oleh proses penggalian dan penutupan sarang oleh induk yang menyebabkan mikroorganisme terdispersi ke seluruh bagian. Keadaan ini akan bertambah buruk jika dalam satu sarang ditemukan beberapa telur yang infertil atau fertil tetapi tidak mampu berkembang sempurna sehingga dapat memicu kolonisasi jamur dan mengancam perkembangan seluruh telur (Robinson et al., 2003). Telur penyu yang telah rusak dan busuk dapat memengaruhi telur-telur lainnya yang berada dalam satu sarang, sehingga tingkat keberhasilan penetasan dalam sarang tersebut menurun akibat masuknya infeksi dari jamur (Verweij dan Brandt, 2007). Potensi lain penyebab tumbuhnya jamur adalah kontaminasi saat pemindahan telur dari sarang alami ke sarang semi alami. Penggalian dan pengambilan telur di sarang semi alami dilakukan oleh pihak koservasi tanpa menggunakan sarung tangan sehingga dapat terjadi perpindahan jamur dari tangan petugas penggali ke telur penyu. Sanitasi peralatan dan pemindahan telur yang kurang baik juga berpotensi sebagai sumber pencemaran, contohnya ember plastik tempat menaampung sementara sebelum telur penyu dipindahkan (Haprabu, 2018).

\section{KESIMPULAN}

Dapat disimpulkan bahwa dari 22 sampel pasir diperoleh sebanyak 3 sampel (13.6\%) tidak ditemui adanya pertumbuhan jamur dan 19 sampel (83.4\%) ditemukan jamur. Berdasarkan 
hasil penelitian telah ditemukan 32 koloni jamur yang ditemukan dari 22 sampel pasir dari sarang penyu semi alami di Pantai Sukomade. Jamur yang berhasil teridentifikasi antara lain Aspergillus sp., Cunninghamella sp, Fusarium $s p$ dan Tricoderma sp. Jamur Aspergillus ditemukan sebanyak 6 koloni (21\%), jamur Cunninghamella sebanyak 6 koloni (21\%), jamur fusarium sebanyak 12 koloni $(41 \%)$ dan jamur Trichoderma sebanyak 5 koloni (7\%).

\section{UCAPAN TERIMA KASIH}

Penulis mengucapkan terimakasih kepada Universitas Airlangga PSDKU Banyuwangi atas dukungan fasilitas sehingga penelitian ini dapat diselesaikan. Peneliti juga mengucapkan terimakasih kepada pihak Taman Nasional Meru Betiri sehingga penelitian dapat dilaksanakan dengan baik.

\section{DAFTAR PUSTAKA}

Al-mohanna. 2017. Methods For Fungal Enumeration, Isolation And Identification. University of Al-Qasidiyah. Research gate, 156-156.

Anwar, S., Febria, F.A., Nasir, N. 2014. Identifikasi Koleksi Jamur dari Cangkamg dan Pasir Sarang Telur Penyu Lekang (Lepidochyles olivaceal) di Penangkaran Pariaman. Biologi Universitas Andalas, 3(1), 46-50.

Ario, R., Wibowo, E., Pratikto, I., Fajar, S. 2016. Pelestarian Habitat Penyu dari Ancaman Kepunahan di Turtle Conservation And Education Center (TCEC). J. Kelautan Trop., 19(1), 60-66.

Blinski, J., Reina, J., Spotila, R.D., Paladino, F.V. 2001. The effects of nest environment on calcium mobilization by leatherback turtle embryos (Dermochelys coriacea) during development. Comparative Biochemistry and Physiology Part A: Mol. Integra. Physiol., 130(1), 151-162.
Bruner, D.W., Illespie, G.H. 1973. The family Picornaviridae. Hagan's Infectious Disease of Domestic Animals, 6, 1207-1028.

Candan, E.D. 2018. Molecular Identification of Fungal Isolates and Hatching Succes of Green Turtle (Chelonia mydas) Nest. Arch Microbiol., 200(6), 911-919.

CITES. 2015. Checklist of CITES Species. Diakses pada http://checklist.cites.org.

Clusella, T.S., Paladino, F.V. 2007. Microenvironment of Olive Ridley Turtle Nest Deposited Durin an Agregated Nesting Event. J. Zool., 272, 367- 376.

Elfidasari, D.T. Gifari, I., Sugoro. 2018. Deteksi Cemaran Mikroorganisme pada Kawasan Konservasi Penyu di Pangumbahan Sukabumi. J. Al-Azhar Indonesia, 4(1), 2835.

Elshafie, A., Saif, N., Al-Bahry, Abdulaziz, Y., Alkindi, T. Ba-Omar, Mahmoud, I. 2007. Mycoflora and Aflatoxins in Soil, Eggshells, and Failed Eggs of Chelonia mydas at Ras Al-Jinz, Oman. Chelonian Conserv. Biol., 6(2), 267-270.

Frisvad, J. C., Larsen, T.O., Thrane, U., Meijer, M., Varga, J., Samson, R.A., Nielsen, K.F. 2011. Fumonisin and ochratoxin production in industrial Aspergillus niger strains. PLoS One, 6(8), 234-296.

Grossman, M.E. 2012. Cutaneous Manifestations of Infection in the Immunocompromised Host. Springer Science Business Media.

Güçlü, Özgür, Biyik, Halil., Şahiner, A. 2010. Mycoflora identified from loggerhead turtle (Caretta caretta) egg shells and nest sand at Fethiye beach, Turkey. Afr. J. Microbiol. Res., 4, 408-413. 
Haprabu, B.R.S. 2018. Isolasi dan Identifikasi Cemaran Bakteri Escherichia coli pada Telur Penyu Lekang yang Gagal Menetas di Sarang Semi Alami Pantai Boom Banyuwangi. [Skripsi]. Fakultas Kedokteran Hewan. Universitas Airlangga.

Ismaiel, A.A., Jutta, P. 2015. Mycotoxins: Producing Fungi and Mechanisms of Phytotoxicity. J. Agric., 5, 492-537.

IUCN. 2008. The IUCN Red List of Threatened Species. ISSN 2307-8235 Jansen. 2003. Green Sea Turtle. University of San Francisco Library.

Mirocha J., Chester, J., Pawlosky, Robert, Hamed, A. 1989. Analysis of T-2 toxin in a biological matrix using multiple reaction monitoring. Arch. Environ. Contamination Toxicol., 18, 349-55.

Mo, C.L., I. Salas, M., Caballero. 1990. Are fungi and bacteria responsible for olive ridley's egg loss? In proceedings of the 10th annual workshop on sea turtle biology and conservation. NQAA Technical Memorandum NMFS-SEFC, 278, 249-252.

Neves, M.S.C., De Melo, M.C.C., De Oliveira, L.G. 2015. Mycobiota from the eggs, nests and stillbirths of Eretmochelys imbricata Linneus 1766 (Testudines: Cheloniidae) in Pernambuco State, Brazil. Afr. J. Microbiol. Res, 9, 1195-1199.

Nursid, M., Pratitis, A., Chasanah, E. 2010. Kultivasi Kapang MFW-01-08 yang Diisolasi dari Ascidia Aplidium longithorax dan Uji Aktivitas Sitotoksiknya terhadap Sel Kanker Payudara T47D. Pascapanen dan Bioteknologi Kelautan dan Perikanan, 5(2), 103-110.

Palys, T. 2008. Purposive Sampling. The Sage Encyclopedia of Qualitative Research Methode, 2, 697-698.
Peters, A., Verhoeven, K.J.F., Strijbosch, H. 1994. Hatching and emergence in the Turkish Mediterranean loggerhead turtle, Caretta caretta: natural causes for egg and hatchling failure. Ecol, 60, 946-955.

Phillott, A.D., Parmenter, C.J., Limpus, C.J. 2001. Occurrence Of Mycobiota In Eastern Australian Sea Turtle Nests. Memoirs of the Queensland Museum, 49(2), 701-703.

Phillott, A.D., Parmenter, C.J. 2001. The distribution of failed eggs and the appearance of fungi in artificial nests of green (Chelonia mydas) and loggerhead (Caretta caretta) sea turtles. Aust. J. Zool., 49, 713- 718.

Phillott, A.D., Parmenter, C.J., Limpus, C.J., Harrower, K.M. 2002. Mycobiota as acute dan chronic cloacal contaminants of female sea turtles. J. Zool., 50, 687- 695.

Phillott, A.D., Parmenter, C.J., Limpus, C.J. 2004. Occurrence of mycobiota in eastern Australian sea turtle nests. Mem. Qld. Mus., 49, 701-703.

Praja, R.N., Yudhana, A., Haditanoyo, W. 2018. Isolasi Dan Identifikasi Jamur Pada Cangkang Telur Penyu Lekang (Lepidochelys Olivacea) Gagal Menetas Di Pantai Boom Banyuwangi. Surabaya. J. Med. Vet., 1(2), 11-15.

Purnama, M.T.E., Samik, A. 2014. Potential mycotoxin binders on histopathology of the mammary gland experiencing neoplasia in pregnant mice (Mus musculus) with exposed zearalenone. Vet. Med., 7(1), 73-80.

Rafferty A.R., Reina, R.D. 2012. Arrested embryonic de-velopment: a review of strategies to delay hatching in egg-laying reptiles. Proc. R. Soc, 279, 2299-2308.

Rafiza., E., Raharjo, I., Farida. 2014. Pengaruh Kedalaman Sarang Terhadap Masa Inkubasi 
Persentase Keberhasilan Penetasan Telur Penyu Hijau (Chelonia mydas) di Pulau Wie

Kabupaten Bintan. [Skripsi]. Universitas Muhamaddiyah Pontianak.

Robinson, T., McMullan, G., Marchant, R., Nigam, P. 2003. Remediation of dyes in textile effluent: a critical review on current treatment technologies with a proposed. Alternative. Bioresource Technol., 77, 24755.

Rosado-Rodríguez, G., Maldonado-Ramirez, S.L. 2016. Mycelial fungal diversity associated with the leatherback sea turtle (Dermochelys coriacea) nests from western Puerto Rico. Chelonian Conserv. Biol., 15, 265-272.

Salisbury, F.B., Ross, C.W. 1995. Fisiologi Tumbuhan. Institut Tehnologi Bandung Press, p132-135.

Sanjaya, Y., Nurhaeni, H., Halimah, M. 2010. Isolasi, Identifikasi, dan Karakterisasi Jamur Entomopatogen dan Larva Spodoptera litura (Fabricius). Bionatura-Jurnal Ilmu-ilmu Hayati dan Fisik, 12(3), 136 - 141.
Sarmiento-Ramirez, E., Abella, M.P., Martm, M.T., Telleria, L.F., Lopezjurado, A., Marco, Dieguezuribeondo, J. 2010. Fusarium solani is responsible for mass mortalities in nests of loggerhead sea turtle, Caretta caretta, in Boavista, Cape Verde. FEMS Microbiol. Lett., 312, 192-200.

Simbolon, D. 2008. Penambahan Mikroorganisme dan Asam Humik pada Tanah Latosol dan Tanah Tailing untuk Meningkatkan Pertumbuhan dan Produksi Tanaman Jagung (Zea mays). [Skripsi]. Institut Pertanian Bogor.

Verweij, P.E., Brandt, M.E. 2007. Aspergillus Fusarium, and other opportunitistic moniliaceous fungi. In: Murray et al. (eds). Man. Clin. Microbiol., Ch. 121. 9th ed. ASM Press, p124.

WWF 2009. Peta Konservasi Penyu di Indonesia. Diakses pada http://awsassets.wwf.or.id. 